http://kitaibelia.unideb.hu/

ISSN 2064-4507 (Online) • ISSN 1219-9672 (Print)

(C) Department of Botany, University of Debrecen, Hungary

23 (2): 133-140.; 2018

DOI: $10.17542 /$ kit.23.133

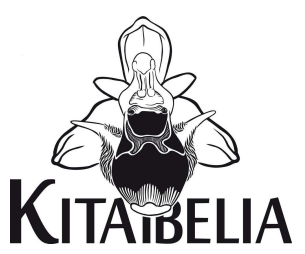

\title{
A Grimmia plagiopodia Hedw. természetvédelmi helyzete Magyarországon
}

\author{
NAGY József ${ }^{*}$ \& PAPP Beáta ${ }^{2}$ \\ (1) Szent István Egyetem, Kertészettudományi Kar, Növénytani Tanszék és Soroksári Botanikus Kert, \\ H-1118 Budapest, Villányi út 29-43.; *Nagy.Jozsef@kertk.szie.hu
}

(2) Magyar Természettudományi Múzeum, Növénytár, H-1431 Budapest, Pf. 137.

\section{Conservational status of Grimmia plagiopodia Hedw. in Hungary}

\begin{abstract}
Three new localities of the protected and endangered moss species, Grimmia plagiopodia Hedw., were discovered in 2017 in the southern part of Börzsöny Mts (North Hungarian Mountains) at Nagymaros and Kismaros villages. The authors have re-evaluated the threat-status of the species applying the most recent IUCN Red List categories and criteria. According to this, G. plagiopodia can still get the endangered (EN) status in Hungary.
\end{abstract}

Keywords: endangered bryophyte in Hungary, North Hungarian Mts, rare bryophyte in Europe

Összefoglalás - A szerzők a Grimmia plagiopodia Hedw. védett és veszélyeztetett lombosmoha faj három új, 2017-ben megtalált előfordulási adatát közlik Nagymaros és Kismaros községek határából, a Börzsöny hegységből. Az IUCN új kritériumainak felhasználásával elvégezték a faj veszélyeztetettségi státuszának újbóli értékelését Magyarországon. Ennek alapján a G. plagiopodia továbbra is veszélyeztetett státuszra jogosult hazánkban.

Kulcsszavak: Európában ritka mohafaj, Északi-középhegység, Magyarországon veszélyeztetett mohafaj

\section{Bevezetés}

A Grimmia plagiopodia Hedw. (hasastokú őszmoha) kozmopolita elterjedésű lombosmoha (GREVEN 2003), amely teljes elterjedési területén ritka, sehol nem rendelkezik folytonos áreával (ERZBERGER 2009) és szerepel az Európai Moha Vörös Könyvben (R - ritka) (ECCB 1995) is. A készülő új európai moha Vörös Listának is potenciális tagja (HoDGETTS 2015). A hazai Vörös Lista a 2010 előtt ismert három populációja (Visegrád, Boldogkőváralja, Pomáz) alapján (PAPP 2008, ERZBERGER 2009) az IUCN kategóriarendszere (IUCN 2001) szerint veszélyeztetett (EN) státuszba sorolta (PAPP et al. 2010). Néhány további, ORBÁN \& VAJDA (1983) összefoglaló munkájában szereplő előfordulási adatát: Mátra, Disznó-kő; Tihany, Csúcs-hegy ERZBERGER \& SCHRÖDER (2008), valamint ERZBERGER (2009) cáfolta. A budapesti aquincumi (PÉTERFI 1906) és a nagymarosi Templom-völgyből történt említését (GYőRFFY 1920) bizonyító példány híján ERZBERGER (2009) kétesnek tekinti. A faj hazánkban 2001 óta természetvédelmi oltalom alatt áll, eszmei értéke $5000 \mathrm{Ft}$.

A Magyarországgal szomszédos országok közül előfordul Ausztriában, Szlovákiában (ahol sérülékeny - VU) és Romániában (ahol kiemelten veszélyeztetett - CR), összesen pedig 14 európai országból ismert, ebből hétben kapott sérülékeny vagy magasabb fokú veszélyeztetettséget jelző besorolást (HODGETTS 2015). 
A szlovákiai előfordulások egyrészt a Duna-kanyar térségéből, a Kovácspataki-hegyek andezit szikláiról, valamint valószínű behurcolás által a Párkányi híd mellől, egy Duna parti andezit szikláról (Sturovó), másrészt a Zólyom (Zvolen) környéki dombokról ismertek (PILOUS 1951/52).

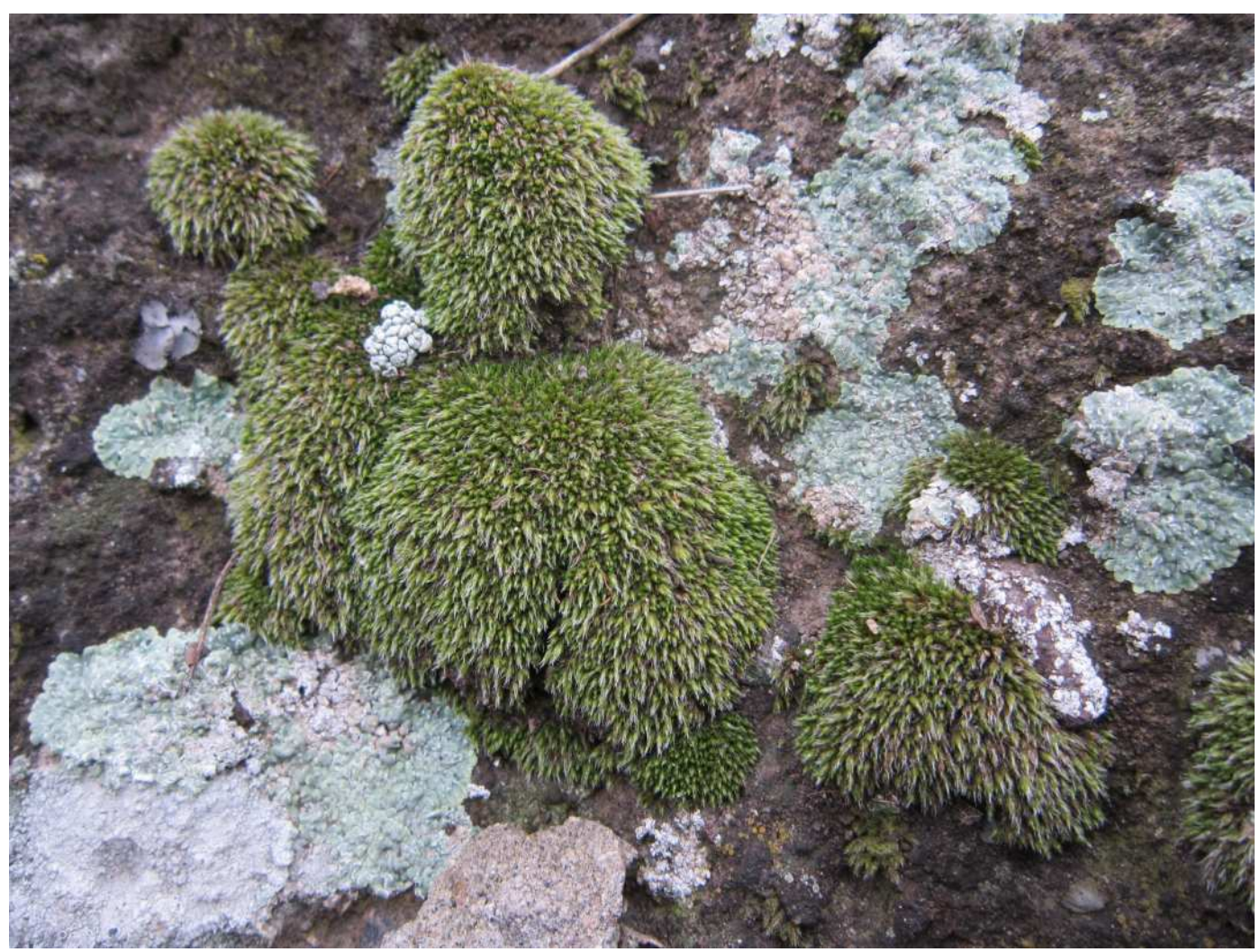

1. ábra. G. plagiopodia párnák a kismarosi Kalló-hegy (KEF 8180.3) dácitszikláin

Fig. 1. Patches of G. plagiopodia on the dacite rocks of Kalló-hill at Kismaros (CEU 8180.3)

A faj jellemzése ERzBerger (2009) és Greven (2003) munkái alapján a következő: Alacsony (0,5-0,8 cm), tömött párnájú, fakó, szürkészöld színű moha (1. ábra). A levél tojásdad, tojásdad-lándzsás, konkáv, zsindelyszerűen egymásra boruló, a csúcsán a szőrszál szélesen illeszkedő, fogazott. Az alsó levelek kisebbek, csúcsuk szőrtelen. A levél lemeze általában egy sejtréteg vastagságú, néha a csúcsnál vagy helyenként a szélén két sejtréteg vastag lehet. A levéllemez sejtjeinek mérete 9-12 $\mu \mathrm{m}$, szabálytalanul kerekedő négyszögletesek, oválisak. Az ér a fonáki oldalon kissé kiemelkedő, a levélcsúcs előtt eltűnik. Gemmák nincsenek. A sporofiton általában megfigyelhető. A tok a perichaetiumba süllyedt, gömbölyded, tojásdad, hasas. A széta görbült, a toknál rövidebb $(0,4 \mathrm{~mm})$, excentrikusan kapcsolódik a tokhoz. A fedő kúpos, kidomborodó, rövid csőrű. A perisztómium fogak szabálytalanul hasadozottak, áttörtek. A faj felismerését megkönnyíti, hogy a szőrszálak jellegzetesen egy irányba simulók.

Jellemző élőhelyei a kopár, konkurenciamentes, napos, száraz szilikát sziklafelszínek, sziklafalak és repedések, de antropogén eredetű termőhelyeken, így várfalakon is megtelepszik. 


\section{Módszer}

2017 folyamán célzott terepi kutatással a Dél-Börzsöny területén három új populációját fedeztük fel és mértük fel a fajnak, valamint GYőRFFY (1920) közel száz éves adata alapján igazoltuk a létezését egy negyedik állományának is. Recens állományadatokat gyűjtöttünk a három korábban ismert és utoljára 2004-ben Papp Beáta által felmért populációról is. 2018 augusztusa elején felkerestük az azonos régióba tartozó szlovákiai Kovácspataki-hegyek szikláiról jelzett állományt, abból a célból, hogy megbecsüljük a populáció méretét, valamint lehetséges hatását a hazai populációra, annak veszélyeztetettsége szempontjából.

Az IUCN 2017-es kritériumait (IUCN Standards and Petitions Subcommittee 2017) alapul véve elvégeztük a $G$. plagiopodia hazai természetvédelmi helyzetének újbóli értékelését, veszélyeztetettségi státuszának megállapítását. Az alábbi kritériumokat használja a rendszer: A. Populációméret csökkenés, B. Földrajzi terület: az előfordulás kiterjedése (B1) illetve az elfoglalt terület nagysága (B2), C. Kis populációméret és csökkenés, D. Nagyon kis populációméret, E. Kvantitatív analízis a kihalás valószínűségére.

Az A kritériumot legalább 10 éves periódusra vagy 3 generációra kell vonatkoztatni. Az előfordulás kiterjedésének (B1) megállapításához az IUCN a szélső helyzetű lokalitások öszszekötésével megállapított terület kiszámítását ajánlja (IUCN 2014). Az elfoglalt terület nagyságának megállapításához (B2) a faj által lakott $2 \times 2$ km-es kvadrátok megadását használja. A populációméret megállapításánál (C, D) a sziklalakó mohák esetében az $1 \mathrm{~m}^{2}$-en előforduló párnák tekinthetők egy egyednek. Az E kritérium alkalmazásához hosszú távú adatsorokkal kell rendelkezni.

A termőhely jellemzésekhez a Magyarország felszíni földtana 1:100 000 MBFSZ térkép geológiai adatait használtuk fel. A terület- és távolságméréseket a Magyarországi Erdészeti Webtérkép alkalmazásával, a szélső helyzetű lokalitások összekötésével végeztük.

\section{Eredmények}

Jelenlegi ismereteink szerint Magyarország területén a G. plagiopodia hét populációja fordul elő (1. táblázat), amelyek öt KEF kvadrátban helyezkednek el (2. ábra).

Az országos állomány 98\%-a a Dunakanyar (Visegrád, Nagymaros, Kismaros, Pomáz) térségében, mintegy $100 \mathrm{~km}^{2}$-en koncentrálódik (4. ábra). A legnépesebb és egyben központi helyzetű visegrádi populációtól a környező állományok távolsága: nagymarosi Nagykő 2,5 km, nagymarosi Szürke-hegy 4,2 km, kismarosi Nagy-Kőszikla 4,7 km, kismarosi Kalló-hegy 5,3 km, pomázi Kő-hegy 14,0 km. A szlovákiai Kovácspataki Sziklák 16 km távolságra találhatók. A boldogkőváraljai populációt önálló fragmentumnak tekintjük.

A Kovácspataki Sziklák jelentős részének bejárása során megtaláltuk a PILOus (1951/52) által onnan jelzett populáció egy részét: Kovácspatak (Szlovákia), Kovácspataki-hegyek (Kováčovské kopce) (2018. VIII. 3.), 47.823500 É, $18.769917^{\circ} \mathrm{K}, 130-250 \mathrm{~m}$ tszf. (KEF 8178.4): $12 \mathrm{~m}^{2}$, 70 párna. Alapkőzet: andezit. Kitettség: déli. Sziklákon, sziklarepedésekben. Tapasztalatunk szerint a G. plagiopodia igen szórványos megjelenésű volt a vizsgált sziklákon, a populációméret nem nagy. Valószínű, hogy a tényleges állomány ugyan néhányszor nagyobb lehet a megtaláltnál, de úgy ítéljük meg, hogy nincs számottevő hatása a VisegrádNagymaros térségében található hazai állományok populációdinamikája és veszélyeztetettsége szempontjából. Ebből a szempontból ugyanis a központi helyzetben levő, a spóraterjesztés szempontjából ideális elhelyezkedésű (320 m tszf., a szeleknek kitett), nagy példányszámú, visegrádi populációt tartjuk meghatározó jelentőségűnek. 
1. táblázat. A populációk lelőhelye, élőhelye és mérete

Table 1. Localities, habitats and size of the populations

\begin{tabular}{|c|c|c|}
\hline & $\begin{array}{l}\text { kiterjedés / } \\
\text { extent }\left(\mathrm{m}^{2}\right)\end{array}$ & $\begin{array}{c}\text { párnákszáma / } \\
\text { no. patches }\end{array}$ \\
\hline $\begin{array}{l}\text { 1. Visegrád, Fellegvár (felmérés: } 2017 \text {. XII. 21.), } 47.79409^{\circ} \text { É, } 18.97980^{\circ} \mathrm{K} \text {, } \\
310-320 \mathrm{~m} \text { tszf. (KEF } 8279.2 \text { ). Alapkőzet: andezit. Kitettség: nyugati. } \\
\text { A várfal alapját képező sziklákon és a várfalon (3. ábra). }\end{array}$ & $\sim 180-190$ & $\sim 1000$ \\
\hline $\begin{array}{l}\text { 2. Nagymaros, Szürke-hegy (2017. VI. 2., VI. 9., VI. 17.), } 47.77027^{\circ} \text { É, } \\
\text { 18.93819 K, 150-170 m tszf. (KEF 8279.2), (új adat). Alapkőzet: } \\
\text { andezit. Kitettség: déli. Sziklafalak repedéseiben. }\end{array}$ & 7 & 40 \\
\hline $\begin{array}{l}\text { 3. Nagymaros, Nagykő a Templom-völgynél (2017. XII. 8.), } \\
47.78919^{\circ} \text { É, } 18.94769^{\circ} \mathrm{K}, 220-250 \text { m tszf. (KEF } 8279.2 \text { ), } \\
\text { (GYőRFFY } 1920 \text { igazolt adata). Alapkőzet: dácitbreccsa. Kitettség: déli, } \\
\text { délkeleti. Sziklákon. }\end{array}$ & 8 & 120 \\
\hline $\begin{array}{l}\text { 4. Kismaros, Nagy-Kőszikla (2017. XI. 25.), } 47.83566^{\circ} \text { É, } 18.97994^{\circ} \mathrm{K} \text {, } \\
320 \text { m tszf. (KEF 8179.4), (új adat). Alapkőzet: dácitbreccsa. } \\
\text { Kitettség: déli. Sziklafalon. }\end{array}$ & 7 & 90 \\
\hline $\begin{array}{l}\text { 5. Kismaros, Kalló-hegy (2017. XI. 1., XI. 11., XII. 8.), 47.83352É, } \\
\text { 19.01641 K, } 200 \text { m tszf. (KEF 8180.3), (új adat). Alapkőzet: dácit. } \\
\text { Kitettség: déli. Sziklákon. }\end{array}$ & 10 & 110 \\
\hline $\begin{array}{l}\text { 6. Pomáz, Kő-hegy (2017. XII. 27.), } 47.67283^{\circ} \text { É, } 19.01466^{\circ} \mathrm{K}, 340 \mathrm{~m} \\
\text { tszf. (KEF 8380.1). Alapkőzet: dácittufa és andezit. Kitettség: déli. } \\
\text { Enyhébb lejtésú sziklagyepben. }\end{array}$ & 2 & 5 \\
\hline $\begin{array}{l}\text { 7. Boldogkőváralja, Boldogkői vár (2017. IV. 13.), } 48.34430^{\circ} \text { É, } \\
21.23258^{\circ} \mathrm{K}, 240-250 \mathrm{~m} \text { tszf. (KEF } 7693.3 \text { ). Alapkőzet: andezittufa. } \\
\text { Kitettség: délies. A várfal alapját képező sziklákon. A populáció } \\
\text { létezését 2017-ben Peter Erzberger erősítette meg. }\end{array}$ & $\sim 5$ & $\sim 30$ \\
\hline Összesen / in all & $\sim 220-230$ & $\sim 1400$ \\
\hline
\end{tabular}

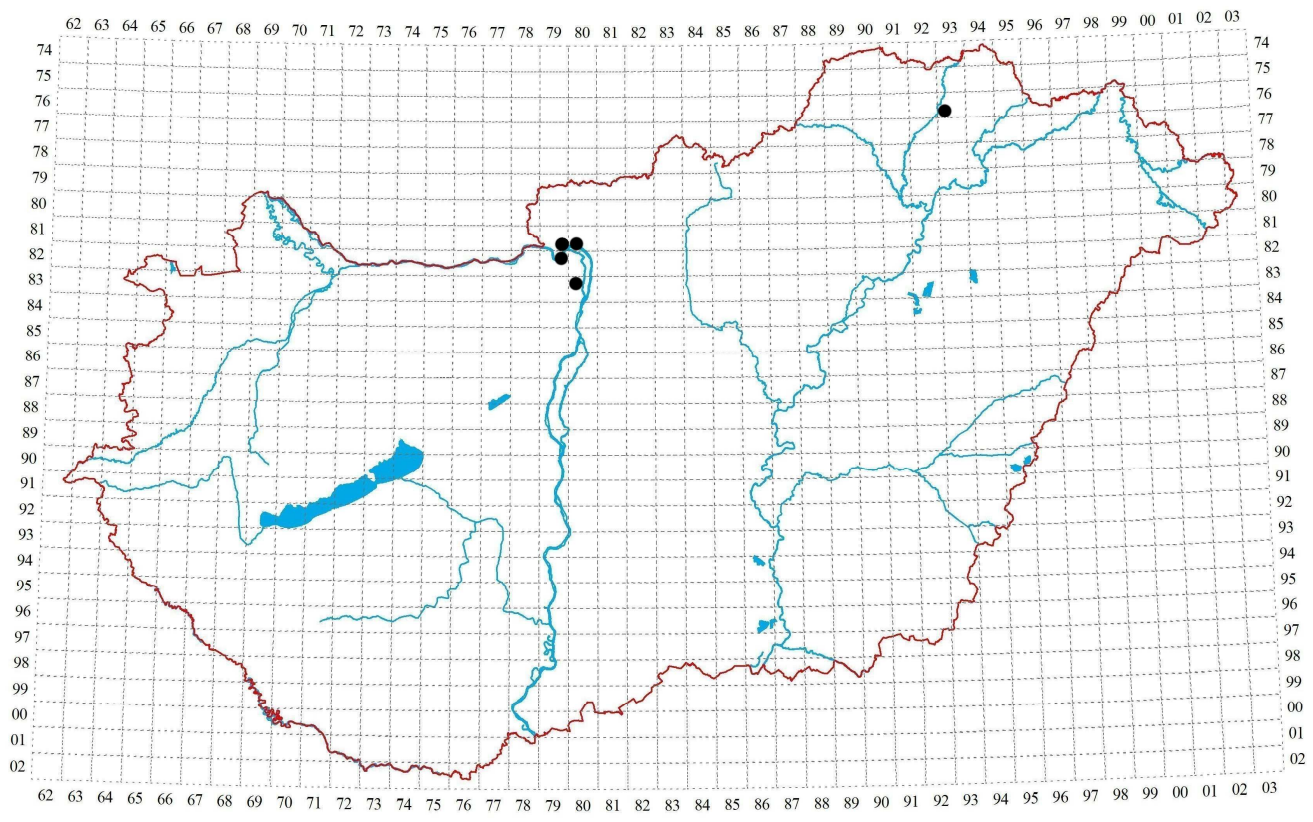

2. ábra. A G. plagiopodia elterjedése Magyarországon

Fig. 2. Distribution of G. plagiopodia in Hungary 
NAGY \& PAPP: A Grimmia plagiopodia természetvédelmi helyzete Magyarországon

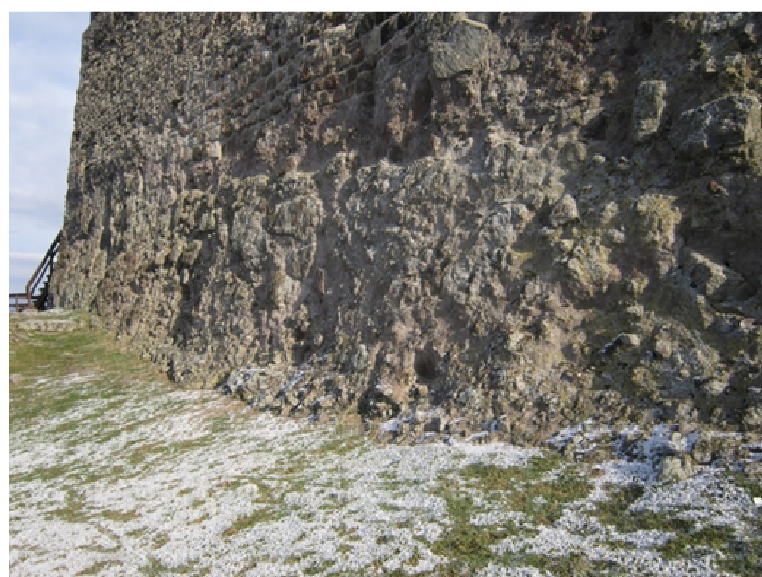

3. ábra. A visegrádi Fellegvár (KEF 8279.2) nyugati falának andezit lábazata

Fig. 3. Andesite bedrock on the western facing part of Visegrád Castle hill (CEU 8279.2)

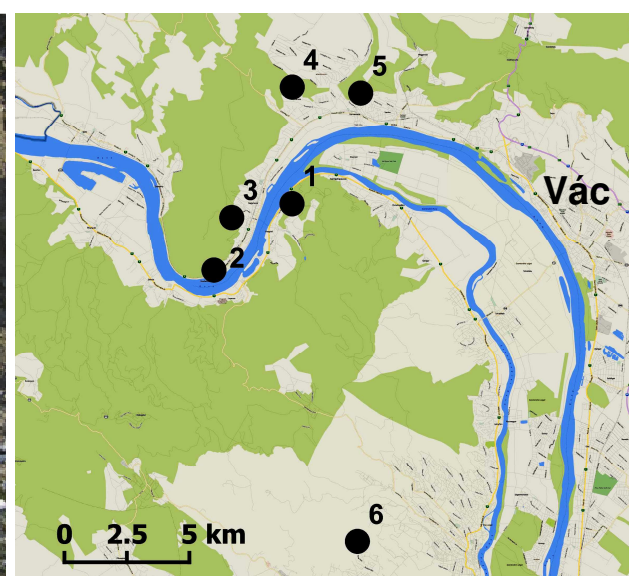

4. ábra. G. plagiopodia előfordulások a Dunakanyar térségében, Magyarországon

Fig. 4. Locations of G. plagiopodia in the Danube Bend territory of Hungary

\section{A faj veszélyeztetettségi státuszának újraértékelése}

Már az IUCN 2014-es veszélyeztetettségi kategóriarendszere (IUCN Standards and Petitions Subcommittee 2014) a mohák esetében is az elterjedésén kívül nagy hangsúlyt fektet a populációméretekre és a fajok helyzetének időbeli változására (PAPP et al. 2014). Az aktuális hazai Moha Vörös Lista (PAPP et al. 2010) alapvetően még az ismert populációk számára alapozta egy-egy faj veszélyeztetettségének a megállapítását. Az IUCN új kritériumai alapján (IUCN Standards and Petitions Subcommittee 2017) a veszélyeztetettség országos, illetve regionális szintű megítélése lényegesen összetettebb feladattá vált. Az új szempontrendszer használata során többféle, lehetőség szerint régi és aktuális megfigyelési adatokra egyaránt szükség van.

Az egyes kritériumok szerinti részletes értékelés (az értékeléshez használt adatok összesítése az 2. táblázatban található):

\section{A. Populációméret csökkenés}

2004. óta országos viszonylatban nem tapasztaltuk, sőt, az újonnan felfedezett állományoknak köszönhetően nőtt az ismert hazai populációméret. Az A kritérium alapján nem veszélyeztetett a faj.

\section{B. Földrajzi terület: az előfordulás kiterjedése (B1) vagy az elfoglalt terület nagysága (B2)}

B1. A hazai előfordulás kiterjedése („extent of occurrence” - EOO) több, mint $100 \mathrm{~km}^{2}$ és kisebb, mint 5000, amely szerint a faj veszélyeztetett (EN) kategóriába sorolható, ha még két további alkritérium is igaz rá. A területmérés alapján, amit a szélső helyzetű lokalitások öszszekötésével végeztünk $2100 \mathrm{~km}^{2}$ lehet a faj hazai areájának kiterjedése.

B2. Az elfoglalt terület („area of occupancy” - AOO) több, mint $10 \mathrm{~km}^{2}$, de lényegesen kisebb mint $500 \mathrm{~km}^{2}$, amely szerint a faj sebezhető (VU), ha még két további alpont is igaz rá. Esetünkben a $2 \times 2 \mathrm{~km}$-es referencia skála alapján az elfoglalt terület $7 \times 4 \mathrm{~km}^{2}=28 \mathrm{~km}^{2}$

Alkritériumok:

a. az ismert lokalitások száma ötnél több, de tíznél kevesebb, így eszerint is sebezhető (VU)

b. a szubpopulációk számának csökkenése pedig bekövetkezhet (kiemelten a pomázi Kőhegy kis állománya veszélyeztetett ebből a szempontból) 
Mivel a két alkritérium szerint a faj sebezhető (VU), így összességében a B kritérium alapján a faj sebezhetőnek (VU) tekinthető Magyarországon.

\section{Kis populációméret és csökkenés}

A hazai teljes populáció becsült egyedszáma kevesebb, mint 250, ami alapján a faj kiemelten veszélyeztetett (CR), ha a további alpontok (C2) közül is valamelyik teljesül.

A sziklalakó mohák esetében az $1 \mathrm{~m}^{2}$-en előforduló párnák egy egyednek tekintendők. Így a hazai populációk területösszege mintegy $220-230 \mathrm{~m}^{2}$, bár a tokos párnák száma eléri az 1400-at.

C2. Csökkenés következhet be a kifejlett egyedek számában és

a. (i), az egyes szubpopulációk mérete nagyobb, mint 50, de kisebb, mint 250. Így C2 alapján a faj veszélyeztetett (EN) kategóriába sorolható.

Összességében a C kritérium alapján értékelve a faj veszélyeztetettnek (EN) minősül hazánkban.

\section{Nagyon kis populációméret}

A becsült hazai populációméret $220-230 \mathrm{~m}^{2}$, vagyis több, mint 50 , de nem éri el a 250 -et. A D kritérium alapján a faj hazai viszonylatban veszélyeztetettnek (EN) tekintendő.

\section{E. Kvantitatív analízis}

Ennek a kritériumnak a megítéléséhez nem rendelkezünk visszamenőlegesen hosszú távú kvantitatív adatokkal.

2. táblázat. A magyarországi G. plagiopodia populációk IUCN kritériumok szerinti értékelése Tab. 2. Evaluation of the Hungarian G. plagiopodia populations according to IUCN criteria

\begin{tabular}{|c|c|c|c|c|c|c|}
\hline & & CR & EN & VU & $\begin{array}{c}\text { Grimmia } \\
\text { plagiopodia }\end{array}$ & státusz \\
\hline $\mathrm{B}$ & Elterjedés & & & & & \\
\hline B1 & előfordulás kiterjedése (EOO) & $<100 \mathrm{~km}^{2}$ & $<5000 \mathrm{~km}^{2}$ & $<20000 \mathrm{~km}^{2}$ & $2100 \mathrm{~km}^{2}$ & EN \\
\hline B2 & elfoglalt terület (AOO) & $<10 \mathrm{~km}^{2}$ & $<500 \mathrm{~km}^{2}$ & $<2000 \mathrm{~km}^{2}$ & $28 \mathrm{~km}^{2}$ & VU \\
\hline $\mathrm{a}$ & lokalitások száma & $=1$ & $\leq 5$ & $\leq 10$ & 7 & VU \\
\hline $\mathrm{b}$ & csökkenés lehetséges & & & & + & VU \\
\hline c & fluktuáció & & & & - & - \\
\hline $\mathrm{C}$ & Populációméret & $<250$ & $<2500$ & $<10000$ & $220-230$ & $\mathrm{CR}$ \\
\hline $\mathrm{C} 1$ & csökkenés a jövőben & $\begin{array}{l}25 \% \text { (3 év; } \\
1 \text { generáció) }\end{array}$ & $\begin{array}{l}20 \% \text { (5 év; } \\
2 \text { generáció) }\end{array}$ & $\begin{array}{l}10 \% \text { (10 év; } \\
3 \text { generáció) }\end{array}$ & $?$ & - \\
\hline $\mathrm{C} 2$ & csökkenés & & & & + & \\
\hline a (i) & szubpopulációk mérete & $\leq 50$ & $\leq 250$ & $\leq 1000$ & $2-190$ & EN \\
\hline a (ii) & $\begin{array}{l}\text { kifejlett példányok száma egy } \\
\text { szubpopulációban }\end{array}$ & $90-100 \%$ & $95-100 \%$ & $100 \%$ & $82 \%$ & - \\
\hline $\mathrm{b}$ & fluktuáció & & & & - & - \\
\hline $\mathrm{D}$ & Kis populációméret & $<50$ & $<250$ & $\mathrm{D} 1,<1000$ & $220-230$ & EN \\
\hline D2 & $\begin{array}{l}\text { kis elfoglalt terület, kevés } \\
\text { lokalitás }\end{array}$ & & & $\begin{array}{c}\text { D2, } \\
\text { A00 <20 km2, } \\
\text { lokalitás } \leq 5\end{array}$ & & \\
\hline
\end{tabular}




\section{Következtetések}

Az IUCN szabályrendszere alapján az öt feltétel közül mindig a legmagasabb fokú veszélyeztetettséget jelentőt vagy jelentőket kell egy faj státuszának megállapítása során figyelembe venni. A G. plagiopodia az IUCN új kategóriarendszerének C és D kritériuma alapján, azaz a populációméretek alapján Magyarországon továbbra is veszélyeztetett (EN) státuszra jogosult. Természetvédelmi szempontból meghatározó jelentőségű a Visegrádi Fellegvárban levő népes állomány megőrzése, ami miatt Magyarország felelőssége európai szinten is nagy. Ugyanakkor az emberi tevékenység miatt éppen ez az állomány a legveszélyeztetettebb. A vár korábbi felújítási és állagmegóvási munkálatainak következtében bekövetkezett fogyásra a populáció mintázata alapján csak következtetni tudunk. Megfigyelhető, hogy a várfalon két kiterjedt állományfolt között mintegy húsz méter hosszú falszakaszról hiányoznak a $G$. plagiopodia párnái. A populáció kedvező állapotának megőrzése érdekében szükséges a briológusok, a természetvédelem és a műemlékvédelem együttmúködése (PAPP 2004). Öt további, kis egyedszámú populáció helyzete stabilnak tekinthető a nehezen megközelíthető, meredek, sziklás élőhelyüknek köszönhetően. A pomázi Kő-hegyen vadjárta andezit sziklagyepben található szélsőségesen kis állományt azonban szintén a kipusztulás fenyegeti.

\section{Köszönetnyilvánítás}

Köszönjük Peter Erzbergernek a terepmunkában nyújtott segítségét és a boldogkőváraljai populációra vonatkozó aktuális adatainak rendelkezésünkre bocsátását, valamint Marko Sabovljević-nek a természetvédelmi értékeléshez adott hasznos észrevételeit, javaslatait. A nagymarosi Nagykő bejárásához nyújtott segítségéért Zeller Zoltánt illeti köszönet.

\section{Irodalomjegyzék}

ECCB (1995): Red data book of European bryophytes. - European Committee for Conservation of Bryophytes, Trondheim, $291 \mathrm{pp}$.

ERzBERGER P. (2009): The genera Grimmia and Coscinodon (Grimmiaceae, Musci) in Hungary - Studia botanica hungarica 40: 37-124.

ERzBERGER P. \& SchröDER W. (2008): The genus Schistidium (Grimmiaceae, Musci) in Hungary. - Studia botanica hungarica 39: 27-88.

Greven H.C. (2003): Grimmias of the World. - Backhuys Publishers, Leiden, The Netherlands, 260 pp.

GYőRFFY I. (1920): Adatok Budapest környékének mohaflórájához I. (Beiträge zur Moosflora der Umgebung von Budapest I). - Magyar Botanikai Lapok 19: 23-31.

HoDGETTS N.G. (2015): Checklist and country status of European bryophytes - towards a new Red List for Europe. - Irish Wildlife Manuals, No. 84. National Parks and Wildlife Service, Department of Arts, Heritage and the Gaeltacht, Ireland, $125 \mathrm{pp}$.

IUCN (2001): IUCN Red List categories and criteria. Version 3.1. - IUCN Species Survival Commission, Gland, Switzerland and Cambridge, UK, $32 \mathrm{pp}$.

IUCN Standards and Petitions Subcommittee (2014): Guidelines for using the IUCN Red List Categories and Criteria. Version 11. - IUCN Species Survival Commission, Gland, Switzerland and Cambridge, UK, $87 \mathrm{pp}$.

IUCN Standards and Petitions Subcommittee (2017): Guidelines for using the IUCN Red List Categories and Criteria. Version 13. - Prepared by the Standards and Petitions Subcommittee, 108 pp. http://cmsdocs.s3.amazonaws.com/RedListGuidelines.pdf

ORBÁN S. \& VAJDA L. (1983): Magyarország mohaflórájának kézikönyve. - Akadémiai Kiadó, Budapest, $580 \mathrm{pp}$. 
PAPP B. (2004): Mohák és természetvédelem (Bryophytes and conservation) - Magyar Múzeumok 10/4: 21-23.

PAPP B. (2008): Selection of Important Bryophyte Areas in Hungary - Folia Cryptogamica Estonica, Fasc. 44: 101-111.

Papp B., Erzberger P., Ódor P., Hock Zs., SzövéNyi P., Szurdoki E. \& Tóth Z. (2010): Updated checklist and red list of Hungarian Bryophytes. - Studia botanica hungarica 41: 31-59.

PAPP B., SzURDoKi E., LockHART N. \& HodGETTS N.G. (2014): Készülőben az új Európai Moha Vörös Könyv Annales historico-naturales Musei nationalis hungarici 106: 157-168.

PÉTERFI M. (1906): Bryológiai közlemények. III. (Bryologische Mitteilungen. III.) - Növénytani Közlemények 5: 46-47.

PIlous Z. (1951/52): Rozšíření mechu Grimmia plagiopodia Hedw. v ČSR. - Československé Botanické Listy, Praha 4: 157-158.

\section{Hivatkozott világháló oldalak}

[1] Erdőtérkép - Magyarországi Erdészeti Webtérkép http://erdoterkep.nebih.gov.hu/ (Hozzáférés: 2018.11.05.)

[2] Magyarország felszíni földtana 1:100 000 MBFSZ térképek https://map.mbfsz.gov.hu/fdt100/ (Hozzáférés: 2018.11.05.)

Beérkezett / received: 2018. 08. 14. • Elfogadva / accepted: 2018. 11. 05. 